\title{
1952 Meeting of the American Medical Association
}

was held June 9-13, 1952, at Chicago. The program of the Session on Allergy was as follows: Officers of Section

Co-Chairmen: Harold A. Abramson, New York; Horace S. Baldwin, New York.Secretary: Hal M. Davison, Atlanta, Ga.

P'sychodynamic Pharmacology of the Treatment of Asthma Harold A. Abramson, New York The Skin Test and its Diagnostic Value in Clinical Allergy John M. Sheldon, Ann Arbor, Mich. Pollen and Mold Allergy in the Southwest

Boen Swinny, San Antonio, Texas

Infectious Factors in Pediatric and Adult Allergy Robert Chobot, New York Panel Discussion on ACTH and Cortisone and their Use in the Allergic Diseases Horace S. Baldwin, New York, Moderator. Panel:

Carl E. Arbesman, Buffalo Giles A. Koelsche, Rochester, Minn. Augustus Gibson, Rahway, N. J. M. Murray Peshkin, New York Albert H. Holland, Chicago Bram Rose, Montreal, Canada 